DOI: https://doi.org/10.24144/2409-6857.2018.1(51).186-190

УДК338.4:658.5-048.34

Газуда М. В., Стеців М. Р.

\title{
ОКРЕМІ АСПЕКТИ КОМУНІКАЦІЙНИХ ФУНКЦЙ УПРАВЛІННЯ НА ЗАСАДАХ ОПТИМІЗАЦІї
}

\begin{abstract}
У статті розглянуто окремі аспекти комунікаційних функиій управління на оптимізаційних засадах. Зазначено, щуо з метою оптимізації комунікаційних функцій управління підприємству потрібно розробити оптимальну модель комунікативних зв'язків, яка уможливить реалізацію окреслених изілей, забезпечуючи при цььому працівників необхідною інформацією $i$ водночас зніме інформаційне перевантаження з керівника. Розглянуто найбільш поширені типи комунікаційних бар'єрів: особисті, фізичні, організачійні, тимчасові бар'єри та комунікаційні перевантаження, запропоновано методи їх уникнення задля створення оптимальної комунікативної функиії управління. Окреслено проблемні питання реалізації комунікаційного менеджменту, вирішення яких сприятиме підвищенню рівня професійної підготовки управлінця, щз дасть йому можливість адекватно та якісно виконувати власні обов'язки приймаючи виважені управлінські рімення.
\end{abstract}

Ключові слова: комунікаційні функиії, формування процесу управління, оптимальна модель комунікативних зв 'язків, типи комунікачійних бар'єрів, комунікативні можливості.

Постановка проблеми. Комунікація, як одна 3 умов успішного керівництва підприємством та його структурними одиницями, є процесом безперервної обробки інформації, прийняття ефективних рішень та спілкування 3 суб'єктами внутрішнього i зовнішнього середовища компанії. В сучасних умовах господарювання варто зважати на те, що керівник підприємства повинен бути комунікативно компетентним, володіти основами управлінської науки, специфічними знаннями i мистецтвом менеджменту, інноваційних та маркетингових підходів. Оскільки керівник у процесі здійснення управлінської діяльності формує мету організації та забезпечує її досягнення, його комунікативна компетентність безпосередньо впливає на забезпечення результативності і реалізацію цілей організації.

Аналіз останніх досліджень i публікацій. Теоретичні і практичні аспекти дослідження процесу управління комунікаціями підприємства та оптимізації комунікативної функції управління вивчалися відомими вітчизняними та зарубіжними вченими, зокрема такими, як А. Демб, Д. Дерлоу, П. Друкер, Дж. Волш, Р. Дафт, Д. Гвішиані, А. Мюллер, Ф. Кузін, В. Кустов, В. Бебик, О. Кузьмін, М. Виноградський, Н. Жигайло, Д. Кіслов,

(C) Газуда Михайло Васильович, д.е.н., професор кафедри економіки підприємства, ДВНЗ «Ужгородський національний університет», м. Ужгород

Стеців Мирослава Романівна, магістр з економіки, ДВНЗ «Ужгородський національний університет», м. Ужгород, тел.: 0502110544, email: stetsivmira@ gmail.com
А. Крамаренко, С. Приживара, Н. Гавкалова, В. Приймак, О. Стельмах, О. Холод, О. Шубін, Н. Шпак, Н. Якіна та ін.

Будь-який суб'єкт господарювання формує власну систему дій для осіб, які приймають рішення, що передбачає здійснення процесів планування, оцінювання, реалізації та контролю, що в цілому зводиться до системи управління. Науковці визначають зазначене поняття як вплив на суб'єкт 3 метою зміни його стану чи підтримки у певному режимі [6]. Управлінська наука вже давно заявила про себе і як наукова категорія, і як важливий інструмент забезпечення ефективного функціонування підприємства. Безпосередньо «управління» як наукова категорія $є$ найбільш широким поняттям, яке охоплює управління соціально-економічними процесами на різних рівнях, від невеликого підприємства чи закладу до національної економіки чи транснаціональної корпорації. Сутність управління підприємством полягає у здійсненні спрямованої, обгрунтованої та інформаційно вираженої дії суб'єкта на об'єкт, ухваленні рішень, забезпеченні їх якісними методами та інструментами [5]. 3 метою здійснення зазначеного процесу на підприємстві потрібно налагодити достатні інформаційні потоки, сформувати організаційну структуру, забезпечити працівників посадовими обов'язками, укласти систему обміну даними та забезпечити інші потреби управління і кожного окремо взятого працівника.

Системно організований комунікаційний процес дозволяє забезпечити злагоджену роботу організації, у ході якої дві чи більше осіб здійснюють обмін даними чи опрацьовують їх, а 
також впливають одне на одного [3]. У науковій літературі існує багатогранність комунікаційних моделей, зокрема Г.-Д. Лассвелла (1948), Шеннона-Вівера (1949), Р. Якобсона (1960), кожна 3 яких $\epsilon$ достатньою базою для обгрунтування i вибору підприємством власної моделі, яка б була для нього оптимальною та результативною [2]. В Україні, на жаль, комунікативний менеджмент відіграє переважно декларативну роль попри широке напрацювання теоретичного матеріалу за тематикою. Вітчизняні компанії не використовують комунікаційних можливостей, оскільки не розглядають їх як реальний ресурс i, відповідно, не дбають про управління ними, що впливає на їх продуктивність і конкурентну позицію.

Формулювання цілей статті. Метою статті $є$ дослідження теоретичних засад комунікативного управління, розроблення моделі комунікаційних зв'язків та окреслення їх місця в управлінні комунікаціями підприємства, а також формування окремих заходів 3 нівелювання комунікативних бар'єрів підприємства через удосконалення комунікативної компетенції управлінців у процесі оптимізації комунікаційних функцій.

Опис основного матеріалу дослідження. Процес оптимізації комунікаційної функції управління $є$ системою, яка містить багатогранність елементів, спрямованих на надання цій функції максимально вигідних характеристик. Розглядати всю комунікаційну систему в сукупності доволі складно, тому, на нашу думку, доцільним є розроблення окремих пропозицій, які у комплексі сприяли б виконанню основного завдання. Водночас комунікація за своєю сутністю $є$ системним явищем, отже й управління комунікаційною функцією повинно бути системним [7]. Тому в рамках оптимізації доцільним є обгрунтування моделі комунікативних зв'язків та окреслення їх місця в управлінні комунікаціями підприємства, розроблення низки рекомендацій щодо уникнення різноманітних комунікативних бар'єрів, а також формування поетапності оцінювання ефективності керування комунікаційною функцією управління для цілей компанії. Передусім для оптимізації комунікаційних функцій управління підприємства потрібно розробити оптимальну модель комунікаційних зв'язків, яка уможливить реалізацію окреслених цілей, забезпечуючи при цьому працівників необхідною інформацією, і водночас зніме інформаційне перевантаження 3 керівника (рис. 1).

Відзначена модель складається 3 трьох основних блоків, серед яких загальне управління комунікаціями підприємства, що перебуває під впливом різних принципів та форм менеджменту, які діють на підприємстві, суб'єктів i функцій управління. Наступним блоком, який перебуває у прямій залежності від попереднього, $\epsilon$ різного роду комунікаційні процеси, кожен 3 яких складається 3 джерела інформації, комунікатора, повідомлення, комунікаційного каналу, комуніканта та звовротнього зв'язку, який у цій підсистемі виконує головну роль, оскільки забезпечує для комунікатора та комуніканта двосторонній інформаційфний обмін. Останнім елементом цієї системи $є$ різноманітні складові та фільтри, які виникають в компанії як результат незбалансованого управління та мають різний вплив на комунікативну систему підприємства. Серед них: соціальні фільтри, лінгвістична складова, поле комунікативного середовища, індивідуально-поведінкові фільтри, семантичні перешкоди, інформаційні шуми.

Наступним важливим елементом процесу оптимізації комунікаційних функцій управління є боротьба з втратами та бар'єрами. Керівники більшості малих та середніх підприємств передають повідомлення вербально. При цьому передача інформації у такий спосіб, як зазначено в науково-методичних джерелах, зазнає найбільших втрат, що засвідчує об'єктивність потреби уникнення занадто великого скупчення комунікаційних бар'єрів. Розглянемо найбільш поширені типи комунікаційних бар'єрів та запропонуємо методи їх уникнення задля створення оптимальної комунікативної функції управління:

1. Особистісні бар'єри, до яких відносять психологічну несумісність, різницю в цінностях та судженнях окремих людей, різну компетентність отримувача і відправника, словашкідники та негативні невербальні звички. Для ï уникнення можна запропонувати пошук керівником особливих «підходів» до всіх членів колективу, застосування методик рефлексивного слухання, спільні навчання 3 тімбілдингу та підвищення кваліфікації, боротьбу 3 власними недоліками.

2. Фізичні бар'єри, які включають відволікаючі шуми, потребу працювати на відстані та перешкод зв'язку. 3 метою уникнення ix негативного впливу можна застосовувати спілкування в особистих кабінетах чи неформальних місцях, позбавлених зайвого шуму, за неможливості особистих зустрічей використання скайп-зв'язку та інших додатків, які дозволяють максимально наблизити спілкування до реальних умов. 

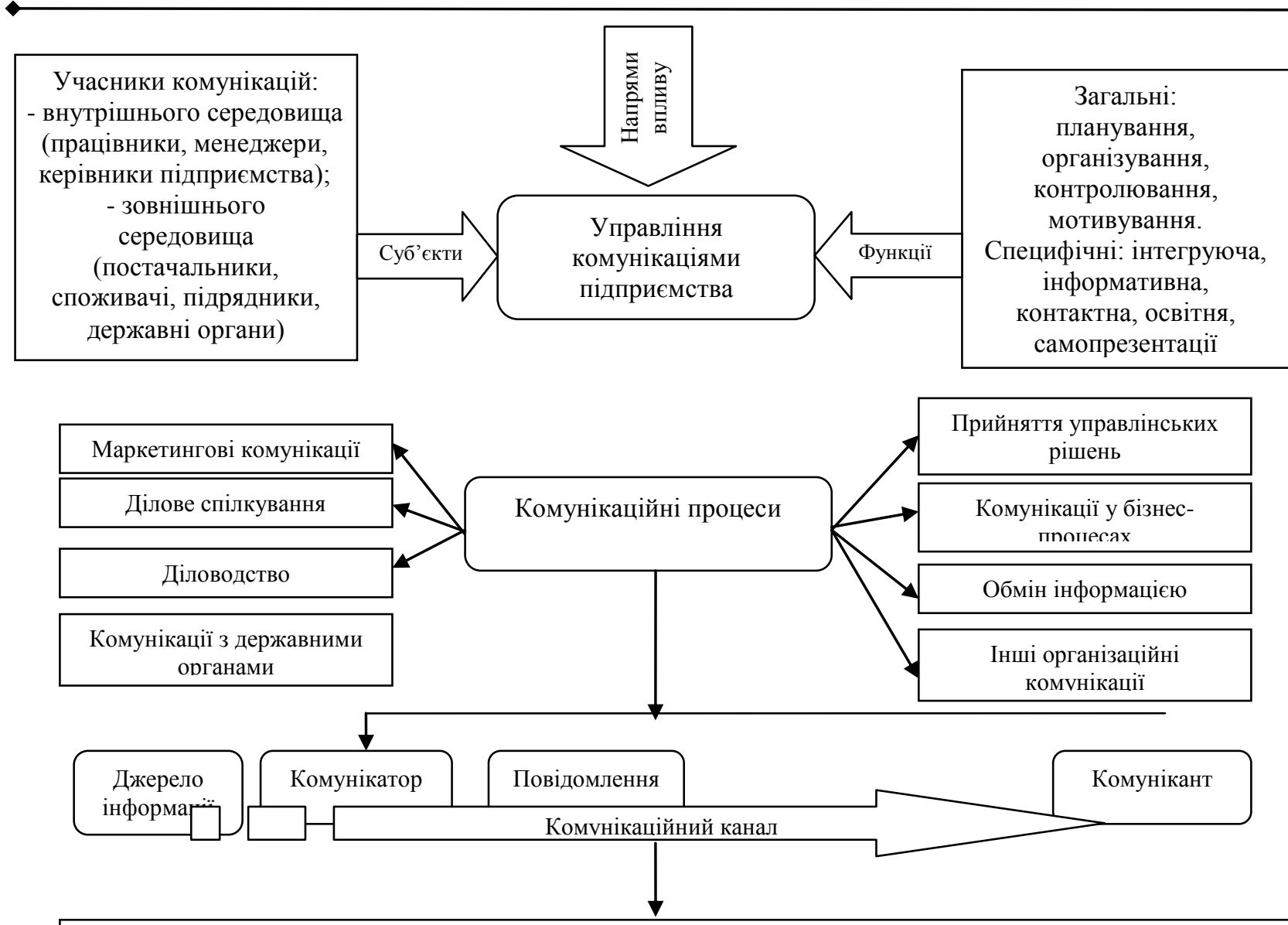

Соціальні фільтри, лінгвістична складова, поле комунікативного середовища, індивідуально-поведінкові фільтри. семантичні перешкоди. інформашійні шуми

\section{Рис 1. Модель комунікаційних зв'язків та їх місця в управлінні комунікаціями підприсмства*}

\section{*Розроблено авторами}

3. Організаційні бар'єри, до яких належать похибки в управлінській структурі, зокрема надмірна централізація управління, зайва диференціація підрозділів, дублювання функцій тощо. Сприяти їх подоланню може розвиток керівником власних навичок щодо делегування повноважень, довіра до підлеглих, оптимальний зворотний зв'язок, чіткий розподіл елементів завдання між його виконавцями та якісно прописані штатні правила і обов'язки, перевага колективних завдань.

4. Тимчасові бар'єри. Їх негативний вплив відбувається за рахунок дефіциту часу на спілкування. Такі бар'єри важко мінімізувати через складність роботи керівника та його завантаженість, тому для уникнення негативного ефекту можна пропонувати розподіляти власний час керівника таким чином, щоб комунікації не страждали за рахунок застосування спеціальних щоденників, методик тайм-менеджменту, принципу Парето тощо.

5. Комунікаиійні перевантаження. За природою ці бар'єри схожі з попередніми, вони сприяють тому, що частина повідомлень відсівається без декодування. У такому разі зарадити може вміння доносити суть повідомлення так, щоб подальші уточнення були мінімальними, використання систем розподілу інформації за типами та вмістом для простішої іiі обробки, створення спільних віртуальних просторів (застосування переносних накопичувачів, хмар).

6. Відмінності у статусі, що стосується суто психологічних особливостей людини, коли один 3 учасників комунікації не задає додаткових питань через побоювання виглядати некомпетентним. Для його уникнення доцільно створювати лояльний імідж керівника, 3 метою пояснення підлеглим, що виконання завдання $€$ основною метою, а керівник сприятиме обгрунтуванню особливості щодо його вхідних даних і методики виконання.

Наступним моментом у сприянні процесу оптимізації комунікаційної функції управлінні, як вважають окремі науковці [1; 4] і думку яких ми підтримуємо, є підвищення комунікаційних 
компетенцій керівника, що засвідчує рівень загальної та вузької професійної підготовки управлінця і дає йому можливість адекватно та якісно виконувати власні обов'язки, приймаючи грамотні й виважені управлінські рішення. Нині практика підготовки керівників у контексті комунікаційного менеджменту має кілька недоліків. По-перше, у процесі підготовки і підвищення кваліфікації керівників недостатня увага приділяється саме комунікаційному аспекту, що викликає недоліки у сфері взаємостосунків і особливо гостро відчувається молодими керівниками на початку професійної діяльності. По-друге, зорієнтована комунікативна підготовка управлінців лише на формування комунікативних знань, а не на розвиток комунікативної компетентності й відповідних особистісних якостей.

Достовірність та глобальність зазначених проблем складно обгрунтувати, оскільки управлінець (керівник) самостійно обирає підходи до розвитку власних компетенцій, що сприяє чи не сприяє виконанню довіреного йому відрізку роботи. Існують прості та дієві методи посилення комунікативної підготовки працівників, які за потреби використовуватимуться працівниками організації. Дослідженням підтверджено, що для будь-якого підприємства чи організації доцільним $\epsilon$ пошук власних комунікативних можливостей, розвиток комунікативних здібностей передусім за допомогою різних тренінгів і семінарів, формування індивідуальних підходів до кожної людини, вивчення методик спілкування, встановлення близьких взаємин 3 персоналом. Водночас для виконання основної діяльності підприємству необхідна дієва мережа комунікацій із стейкхолдерами.

Таким чином, незважаючи на існування значної кількості теоретико-практичних методів щодо удосконалення комунікаційних навичок менеджера, проблемою залишається пошук дієвих та результативних механізмів, які необхідно застосовувати 3 метою забезпечення керівників необхідними компетенціями, в тому числі у сфері оптимізації комунікаційних функцій управління.

Висновки i перспективи подальших досліджень. У сучасних умовах функціонування підприємств, зважаючи на необхідність постійного удосконалення власної діяльності для підвищення рівня конкурентоспроможності, особлива увага належить активізації процесу управління, вагомою складовою якого $\epsilon$ окреслення комунікаційних підходів. Управління у сфері комунікацій зумовлюється формуванням механізму взаємодії окремих елементів підприємства у внутрішньому середовищі та зовнішніх суб'єктів, а також системою інформаційного обміну i забезпечення працівників достатньою кількістю даних.

У процесі дослідження 3 метою формування напрямів оптимізації комунікаційних функцій управління, обгрунтовано модель комунікаційних зв'язків підприємства та окреслено їх місце в системі управління комунікаціями. Розроблено пропозиції, що сприяють уникненню чи зменшенню негативної дії через різного роду комунікаційні бар'єри. У сукупності зазначені діï, спрямовані на оптимізацію комунікаційної функції управління підприємством, можуть стати основою подальших наукових досліджень і удосконалення комунікаційної системи підприємств, оскільки поєднують як організацію процесу і нівелювання негативних моментів, так i удосконалення процесу набуття керівниками знань в управлінській сфері щодо забезпечення комунікаційних можливостей організації.

\section{ПЕРЕЛІК ВИКОРИСТАНИХ ДЖЕРЕЛ}

1. Андрущенко Н.О. Формування комунікативної компетенції у процесі підготовки майбутніх менеджерів // Наук. зап. Вінниц. держ. пед. ун-ту ім. М. Коцюбинського. Сер. Педагогіка і психологія : зб. наук. пр. 2008. Вип. 23. С. 154-158.

2. Жигайло Н. Комунікативний менеджмент: навч. пос. Л.: ЛНУ ім. І. Франка, 2012. 368 с.

3. Любченко Н.Л. Система комунікаційного менеджменту підприємства // Економіка та конкурентоспроможність підприємства, 2013. - №10 (48). - С. 40-45.

4. Мурадова Л. А., Ковальова В.І. Розвиток комунікативної компетентності керівника // Репозиторій Харківського національного університету, 2012. URL: http://www.repository.hneu.edu.ua/jspui/bitstream - Haзва 3 екрану.

5. Приживара С.В. Управління як специфічний вид діяльності // ХapPI HAДУ URL: http://www.kbuapa.kharkov.ua/e-book/db/2012-1/doc/1/07.pdf.

6. Тейлор Ф.У. Принципи научного менеджмента [пер. с англ.]. М.: Контроллинг, 1991. 104 с.

7. Яркіна Н.М. Управління підприємством як економічна категорія (теоретичні аспекти) // Держава та регіони. Серія: Економіка та підприємництво, 2014. №1(76). С. 130-136. 


\section{REFERENCES}

1. Andruschenko, N.O. (2008). Formuvannya komunikatyvnoyi kompetentsiyi u protsesi pidhotovky maybutnikh menedzheriv [Formation of communicative competences in the process of preparing future managers]. Nauk. zap. Vinnyts. derzh. ped. un-tu im. M. Kotsyubyns'koho. Ser. Pedahohika i psykholohiya - Scientific journal of Vinnytsia State Pedagogical University of M. Kotsyubinsky. Ser. Pedagogy and psychology, 23, 154-158 [in Ukrainian].

2. Zhyhailo, N. (2012). Komunikatyvnyy menedzhment: navch. pos. [Communication management: tutorial]. L.: LNU of I. Franko [in Ukrainian].

3. Liubchenko, N.L. (2013). Systema komunikatsiynoho menedzhmentu pidpryyemstva [Communication management system of an enterprise]. Ekonomika ta konkurentospromozhnist' pidpryyemstva - Economy and competitiveness of an enterprise, 10 (48), 40-45 [in Ukrainian].

4. Muradova, L.A. \& Kovaliova, V.I. (2012). Rozvytok komunikatyvnoyi kompetentnosti kerivnyka [Development of manager's communicative competence]. Repozytoriy Kharkivs'koho natsional'noho universytetu - Repository of Kharkiv National University. Retrieved from: http://www.repository.hneu.edu.ua/jspui/bitstream/ [in Ukrainian].

5. Pryzhyvara, S.V. (n.d.). Upravlinnya yak spetsyfichnyy vyd diyal'nosti [Management as a specific type of activity]. Retrieved from: http://www.kbuapa.kharkov.ua/e-book/db/2012-1/doc/1/07.pdf [in Ukrainian].

6. Tailor, F. (1991). Pryntsypy nauchnoho menedzhmenta [Principles of scientific management]. M.: Kontrolling [in Russian].

7. Yarkina, N.M. (2014). Upravlinnya pidpryyemstvom yak ekonomichna katehoriya (teoretychni aspekty) [Management of an enterprise as economic category (theoretical aspects)]. Derzhava ta rehiony. Seriya: Ekonomika ta pidpryyemnytstvo - State and regions. Series: Economics and Business, 1(76), 130-136 [in Ukrainian].

Одержано 15.03.2018 p. 